\title{
CHARACTERISTICS OF POCKET GOPHER POPULATIONS \\ IN RELATION TO SELECTED ENVIRONMENTAL FACTORS IN \\ PELICAN VALLEY, YELLOWSTONE NATIONAL PARK
}

C. C. Youmans

R. E. Moore

Biology Department

Montana State University

\section{Objectives}

Several important environmental factors which affect the dynamics of pocket gopher populations have been identified: water content at peak snowpack and depth of snow in spring (Hansen and Ward, 1966; Reid, 1973); weather and its influence on annual food supplies and cover (Howard and Childs, 1959); production of annual and perennial forbs (Keith et al., 1959; Tietjen et al., 1967); and ground water levels and snow depths (Ingles, 1949; Hansen, 1962). A need for specific information on pocket gophers in Pelican Valley, Yellowstone National Park arose from interest in interactions between grizzly bears (Ursus arctos horribitis) and northern pocket gophers (Thomomys talpoides). Mealey (1975) and Graham (1978) suggested that pocket gophers and their caches may serve as seasonally important food items for grizzlies in Yellowstone National Park.

Objectives of this study were to select specific representative sites in Pelican Valley on which pocket gopher numbers could be quantified, monitored, and compared with data gathered concurrently on vegetative composition, standing crop, soil moisture, soil texture, and snow melt phenology. Changes in pocket gopher numbers were analyzed by gathering data on pocket gopher natality, sex ratios, age structure, annual population turnover, recruitment, period of peak parturition, and home range size. Frequency of infection with the parsitic nematode Capillaria hepatica, average weights, and compositon of a pocket gopher cache were also determined.

Field work was conducted from June to September in 1977 and from June to October in 1978. The final report, a Master of Science thesis by c. Youmans, has been completed, and copies have been mailed to the Rocky Mountain Regional office, National Park Service, Denver, Colorado.

\section{Summary of Results and Conclusions}

Characteristics of pocket gopher populations in relation to vegetation, soil texture, soil moisture, and snow melt phenology were measured on nine belt transects $(100 \mathrm{~m}$ by $10 \mathrm{~m}$ ). Pocket gopher numbers on belt transects were indexed from 48-hour mound counts and trapping. Three hundred-one pocket gophers were dead-trapped during the study. Mound- 
building activity was lowest after snow melt in June and generally highest in August. Mound counts were not a reliable index of gopher numbers when taken prior to late July. Abundance of winter soil casts in June 1978 was correlated significantly $(P<.05)$ with mound counts from the previous late summer and fall of 1977.

The period of peak parturition was determined to be from mid-April to mid-May. Placental scars were persistent and quantifiable and enabled computation of a mean litter size of $4.9(n=67)$. Maximum litter size recorded was seven. Females had significantly $(P<.025)$ larger litters $(\bar{x}=5.1)$ their second (1978) reproductive effort than their first (1977, $\bar{x}=4.4)$. Significant $(P<.025)$ differences in fertility occurred between 50 females collected from Festuca idahoensis/Deschampsia caespitos $a$ habitat types $(\bar{x}=4.7)$ and 42 females collected from Artemisia cana/Festuca idahoensis community types $(\bar{x}=5.2)$.

Population turnover averaged 76.5 percent on two belt transects which were live-trapped. Production of young exceeded replacement requirements. Juveniles composed 80 percent of 64 pocket gophers dead-trapped in September, 1978.

Combined line intercepts of Melica spectabilis and Perideridia gairdneri correlated significantly $(P<.01)$ with 48-hour mound counts (Fig. 1). Abundance of ColZomia Zinearis also correlated significantly $(P<.01)$ with 48-hour mound counts (Fig. 2). Soil textures on belt transects did not appear to influence pocket gopher numbers; however soil depths and soil temperatures may have done so. Soil moisture limited distribution of pocket gophers. Swales were typically too wet for pocket gopher use until late summer. Dispersing juveniles established territories on the edge of swales in August, when soil moisture was lowest. Marked differences in the depth of snow on 1 May between 1977 and 1978 did not appear to influence juvenile survival and hence fall population levels.

\section{Literature Cited}

Graham, D. C. 1978. Grizzly bear distribution, use of habitats, food habits and characterization in Pelican and Hayden Valleys, Yellowstone National Park. M.S. Thesis. Montana State Univ., Bozeman, MT. $88 \mathrm{pp}$.

Hansen, R. M. 1962. Movements and survival of Thomomys talpoides in a mima-mound habitat. Ecology, 43(1):151-154.

and A. L. Ward. 1966. Some relations of pocket gophers to rangeland on Grand Mesa, Colorado. Colo. State Univ. Agr. Exp. Sta. Tech. Bull. 88. 22 pp.

Howard, W. E. and H. E. Childs, Jr. 1959. Ecology of pocket gophers with emphasis on Thomomys bottae mewa. Hilgardia, 29(7):277-358. 
Ingles, L. G. 1949. Ground water and snow as factors affecting the seasonal distribution of pocket gophers, Thomomys monticola. J. Mamma 1., 30(4):343-350.

Keith, J. O., R. M. Hansen, and A. L. Ward. 1959. Effect of 2, 4-D on abundance and foods of pocket gophers. J. Wildl. Manage., $23(2): 137-145$.

Mealey, S. P. 1975. The natural food habits of free ranging grizzly bears in Yellowstone National Park, 1973-1974. M. S. Thes is, Montana State Univ., Bozeman, MT. 158 pp.

Reid, V. H. 1973. Population biology of the northern pocket gopher. Colorado St. Univ. Exper. Sta. Bull., 554-s:21-41.

Tietjen, H. P., C. H. Halvorson, P. L. Hegdal, and A. M. Johnson. 1967. 2, 4-D herbicide, vegetation, and pocket gopher relationships, Black Mesa, Colorado. Ecology, 48(4):634-643. 


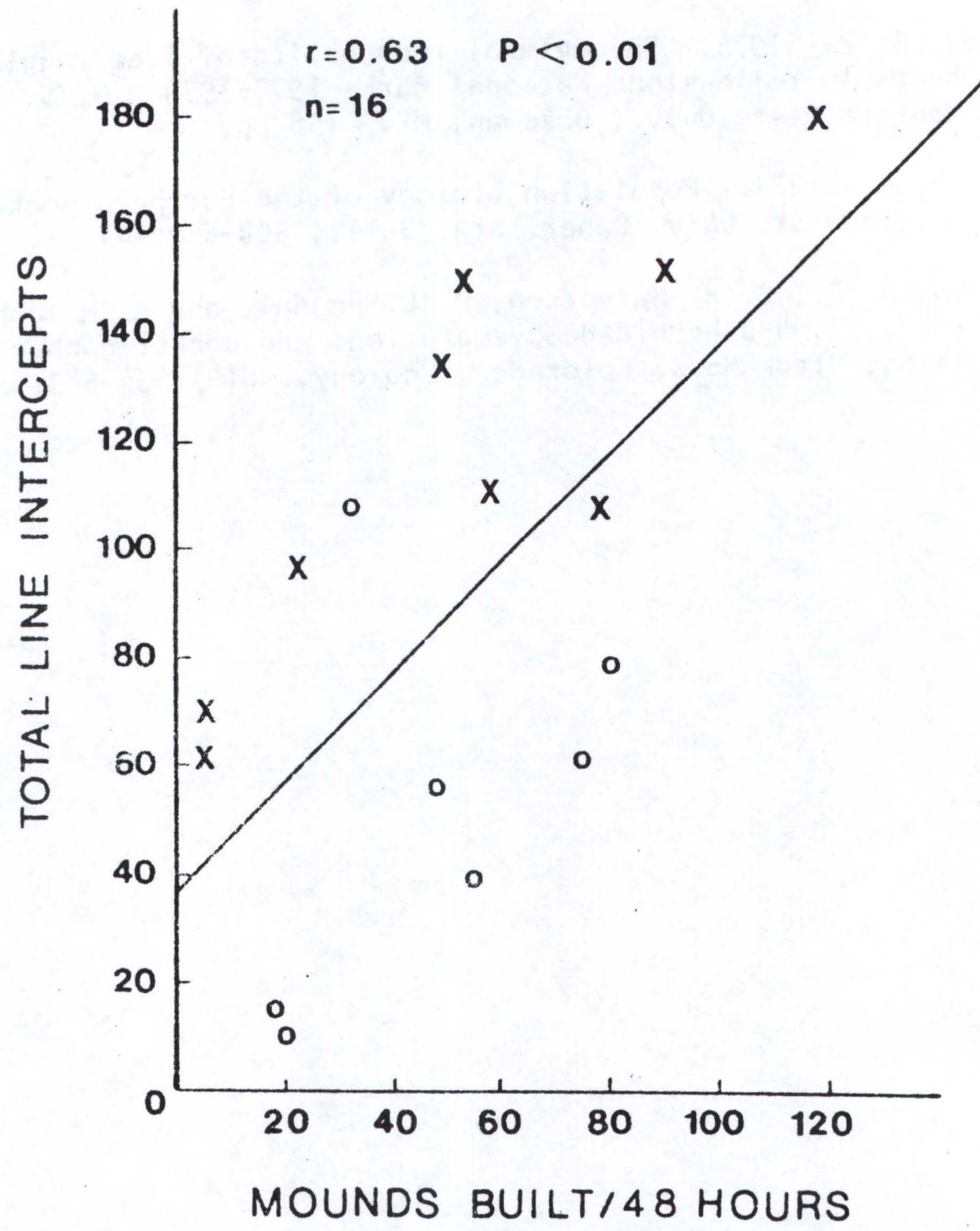

Figure 1. Correlation of combined line intercepts of $P$. gairdneri and $M$. spectabilis on each of 9 belt transects to latesummer mound counts on each belt transect for 1977 (o) and $1978(\mathrm{X})$. 


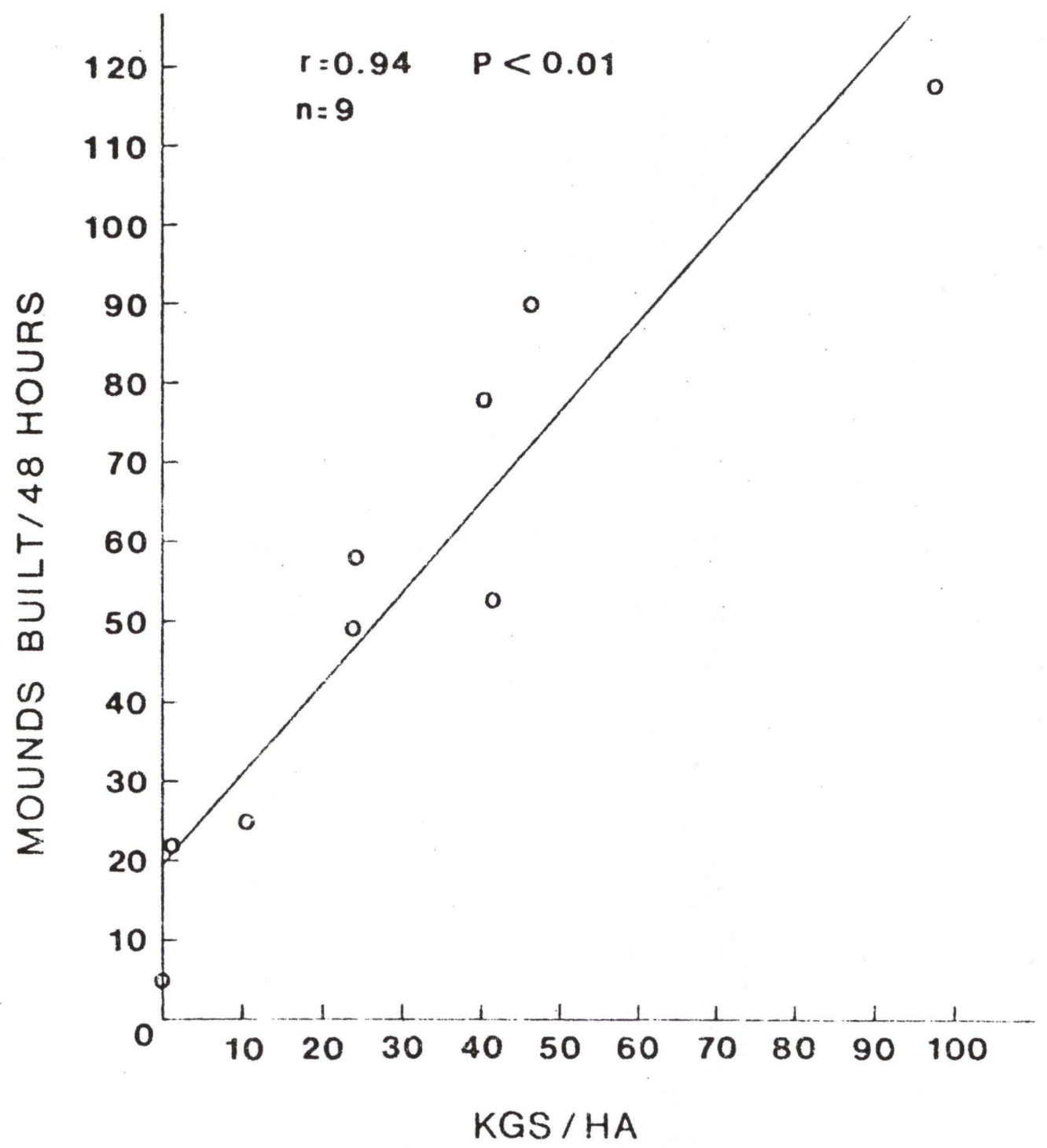

Figure 2. Correlation of C. Zinearis standing crop (kg/ha) and mounds built/48 hours on nine belt transects during August, 1978. 